\title{
Ihmiset oppivat elämällä
}

\section{Antikainen, Ari \& Huotelin, Hannu (toim.) 1996. Oppiminen ja elämänhistoria. Aikuiskasvatuksen 37. vuosikirja. Jyväskylä : BTJ Kirjastopalvelu Oy, 327 s.}

Elinikäisestä kasvatuksesta ja oppimisesta on Suomessakin puhuttu 1960-luvulta lähtien koulutussuunnittelun periaatteena. Käsite on vakiintunut tarkoittamaan koulutusjärjestelmää, joka onkin pitkään ollut Suomea rakentava ja koossapitävä kitti. Yksin ei koulutusjärjestelmä kuitenkaan valmista ihmisiä elämäntaipaleille, vaikka tällaiseen päätelmään saattaisi tullakin, kun selaa pääosin muodolliseen koulutukseen keskittynyttä kasvatustieteellistä tutkimusta tai alan komiteamietintöjä. Elämä opettaa myös ja ennen kaikkea itse. Oppiminen ja elämänhistoria kirjan tulos onkin tiivistettävissä lyhyesti - enemmän kuin kouluttautumalla, ihmiset oppivat elämällä.

Ari Antikaisen johtama tutkimusryhmä on ottanut keskeiseksi tavoitteekseen tutkia eri ikäisten suomalaisten eletyn elämän oppimiskokemuksia. Tässä hankkeessa elinikäinen oppiminen viittaa ihmisten jokapäiväisen elämän monituisiin tapahtumiin. Lähtökohtana ovat ihmisten itsensä kertomat elämäntarinat. Tavoitteena on hahmotella kuvaa siitä, miten suomalaiset merkityksellistävät koulutuksensa ja oppimisensa, millainen koulutus- ja oppimismaisema Suomesta piirtyy sodasta näihin päiviin. Elämäntarinoitaan kertovat eri-ikäisten tavallisten suomalaisten lisäksi kaksi erityistä ryhmää, työläistaustaiset nuoret ja opettajat.

Tutkimusprojekti Kasvatuksen merkitystä etsimässä käynnistyi Joensuun yliopistossa professori Antikaisen johdolla vuosikymmenen alussa ja sen tuloksista on raportoitu ahkerasti sekä kansallisilla että kansainvälisillä foorumeilla. Tutkimusryhmä on julkaissut samanaikaisesti aiheesta myös englanninkielisen teoksen, jonka Risto Honkonen on arvioinut Sosiologia-lehdessä. Living in a Learning Society (Falmer Press, 1996) osoittaa hankkeella olevan myös kansainvälistä merkitystä, vaikka tutkimuksen aineisto ja aihe ovatkin perin suomalaisia. Kansainvälinen kiinnostus johtunee siitä, että Suomi on riittävän pieni ja yhtenäinen tutkimuskohde, eräänlainen oppimisyhteiskunnan laboratorio, joka mahdollistaa koko väestön pitkän aikavälin oppimiskokemusten tutkimisen.

Kirja on ensimmäinen vakava hanke maassamme tarkastella kasvatusta ja oppimista sukupolvittain elämänhistoriallisesta perspektiivistä. Elämäkertatutkimus sinänsä ei ole uutta Suomessa. Varsinkin $J P$ Roosin kymmenisen vuotta sitten julkaisema Suomalainen elämä loi Suomessa perustaa elämäkertametodien käytölle yhteiskunnan ja kulttuurin tutkimuksessa.

Oppimisen merkitystä tarkastellaan kirjassa seitsemän artikkelin verran elämänkulun, identiteetin ja merkittävien oppimiskokemusten näkökulmasta. Artikkelien kirjoittajat toimivat Joensuun yliopiston sosiologian laitoksella.

Tärkeällä sijalla käsillä olevassa tutkimuksessa ovat aiempien tilastojen ja haastatteluaineiston analyysin perusteella muodostetut kolme koulutussukupolvea: Sodan ja niukan koulutuksen (-1935 syntyneet), rakennemuutoksen ja kasvavien koulutusmahdollisuuksien (1936-1955) ja hyvinvoinnin ja monien koulutusvalintojen (1956-) sukupolvi. Koulutussukupolvet eivät eroa toisistaan vain koulutuksen ulkoisten puitteiden suhteen, vaan nimenomaan siinä, millainen merkitys koulutuksella on kullekin sukupolvelle.

Jonkin sukupolven kokemukset jostakin toisesta erottaa kullekin sukupolvelle ominainen sukupolviasema, joka kirjoittajien mukaan syntyy nuoruuden ja varhaisaikuisuuden kokemuksista. Sukupolven sisällä 
kokemukset ja elämänkohtalot tietenkin vaihtelevat, mutta perusoletuksena pidetään, että kulloisellakin sukupolvella on yhteisiä jaettuja kokemuksia.

Sukupolven ja sukupolviaseman käsitteet sisältävät ainakin kaksi teoreettisesti kiinnostavaa ongelmaa. Ensinnäkin, kun kokemusten synnylle oletetaan jokin tietty kliimaksi kuten nuoruus tai varhaisaikuisuus, joudutaan olettamaan, että ihminen muodostaa tuona aikana myös kiinteän identiteettinsä, joka pysyy muuttumattomana aikojen saatossa. Toiseksi, kun puhutaan yhteisistä kokemuksista, on kysyttävä, mistä yhteinen syntyy? Yhteisillä kokemuksilla tarkoitetaan historiallisiin tapahtumiin kiinnittyneitä henkilökohtaisia merkityksenantoja. Merkityksenantoketjujen tutkiminen, siis se miten jokin yleinen muuttuu osaksi omaa yksityistä historiaa, vaatii näkökulman pohdintaa: mikä on rakenteen ja merkityksen suhde? Vaikka pulmat ovat teoreettisesti ratkaisemattomia, syntyy tutkijoiden konstruoimista sukupolviasemien eroista kiinnostavia havaintoja koulutuksen merkityksen muutoksista.

\section{Koulutuksen erilainen merkitys eri sukupolville}

Vanhimmalle koulutussukupolvelle koulutus on ihanne elämän muutoin täyttyessä päivittäisen selviytymisen pakkoraoista. Ihanteinen kuva koulutuksen merkityksestä nousee toisaalta niukoista mahdollisuuksista, toisaalta oppiarvojen kunnioituksesta. Kuinka paljon ihanteikkuuden kokemus on elettyä (life as lived), kuinka paljon itselle myöhemmin olosuhteiden parantuessa kerrottua (life as told), on yleisestikin kiintoisa metodologinen kysymys.

Rakennemuutoksen ja kasvavien koulutusmahdollisuuksien sukupolvella yhteisenä kokemuksena korostuu työn ja koulutuksen välineellinen suhde. Koulutus on enenevästi avaamassa mahdollisuuksia sijoittua sukeutuvan kulutus- ja hyvinvointiyhteiskunnan kilparadalle. Monta jää silti vielä kaivelemaan se, ettei kouluja tullut aikoinaan käytyä.

Hyvinvoinnin ja monien koulutusvalintojen sukupolvelle koulutuksen merkitykselle löytyy kaksi ydinteemaa. Toisaalta koulutus on hyödyke, toisaalta itsestäänselvyys. Tälle sukupolvelle koulutusputki tosin mahdollistaa entistä tehokkaamman etenemisen yhteiskunnallisiin asemiin, mutta luo entistä vähemmän perustaa identiteetin rakentamiselle ja elämän kokemiselle mielekkääksi. Koulun sijaan elämän mielekkyyttä etsitään oman minän tutkiskelusta ja erilaisista harrastuksista.

Omana lukunaan kirjassa esitellään merkittäviksi oppimiskokemuksiksi nimettyjä tapahtumia. Merkittävät oppimiskokemukset ovat sellaisia kokemuksia, jotka ovat muistettavalla ja koetulla tavalla vaikuttaneet yksilön elämään: ohjanneet elämänkulkua, muuttaneet tai vahvistaneet identiteettiä. Merkittävät oppimiskokemukset kiinnittyvät elämän siirtymävaiheisiin, käännekohtiin ja katkoksiin. $\mathrm{Ne}$ ovat siinä mielessä väkeviä, että niissä sekä käsitys omasta elämästä että ympäristöstä muuttuu. Tästä englanninkielisestä kirjallisuudesta tutusta empowermentin ajatuksesta kirjassa käytetään termiä valtautuminen/valtauttaminen.

Merkittävien oppimiskokemusten tematiikka sisältää ainakin kaksi merkille pantavaa havaintoa. Ensinnäkin, merkittävä oppimiskokemus sijoittuu vain harvoin koulun piiriin. Tästä muuallakin tehdystä havainnoista suomalaistenkin koulumestareiden tulisi olla huolissaan. Toiseksi, enemmän kuin oppimisen tutkimuksessa ollaan aiemmin haluttu ymmärtää, oppimisessa ovat tärkeällä sijalla toiset ihmiset ja asiat, oppimisen merkittävät muut. Oppiminen on siis yhteisöllinen asia, jossa on mukana "'minä' (yksilö identiteetteineen), 'me' (yhteisö perinteisessä tai post-traditionaalisessa muodossa) ja 'toiset' (yhteiskunta)" (s. 273). Tämä on varteenotettava havainto ajassamme, jossa tavan takaa korostetaan yksilöä oman onnensa ja oppimisensa takojana. 


\section{Ihmistieteiden ongelmista}

Ihmistieteissä ollaan viimeisten vuosikymmenten aikana eletty läpi lukuisia erilaisia kriisejä. Viimeisin, representaation kriisi, koskettaa erityisen läheisesti elämäkertatutkimuksen tapaisia lähestymistapoja. Kriisiä voidaan katsoa kahdelta puolelta. Toisaalta enää ei voida suoraviivaisesti olettaa, että ihmisistä vaikkapa haastattelemalla saataisiin hahmotettua todellinen kuva, joka heijastaisi todellisuutta. Ilman suoranaista valehteluakin ihmiset kertovat arkipäivän käytännöistään tänään näin, huomenna noin. Elämänkumppanit puhuvat parisuhteen tai perheen ongelmasta ikään kuin kysymyksessä olisi kokonaan toinen ihminen tai perhe. Työyhteisön jäsenet hahmottavat saman tilanteen toisistaan poikkeavasti ikään kuin kyseessä olisi toinen yhteisö.

Toisaalta taas tutkijat ovat yhteiskunnan- ja kulttuurintutkimukseksi nimitetyn käytäntönsä vankeja. Omissa tekstuaaleissa käytännöissään he jähmettävät ihmisten puheita ja tekoja omiksi tulkinnoikseen, ja näistä tulkinnoista syntyy oma todellisuutensa. Näin syntyy (elämäkerta) tutkimusteksti totena sinänsä ja todellisuus tutkimustekstin ulkopuolella jatkaa tapahtumistaan.

Kirjassa annetaan runsaasti tilaa tapauskuvauksille, joissa käytetään ihmisten autenttisia kuvauksia koulukokemuksistaan ja arkipäiväoppimisestaan. Näihin on mahdollista peilata sekä omia kokemuksiaan että hyväksyä tai riitauttaa kirjoittajien niistä tekemät tulkinnat. Kirjoittajat ovat selvästi joutuneet pohtimaan aineistonsa luonnetta em. kriisin näkökulmasta: Kirjoittaako naiivin realistisesti todesta todellisuudesta vai kertoako tarina tarinoista? Miten teoriaa ja empiriaa, rakennenäkökulmaa ja merkitysnäkökulmaa tulisi käsitellä tekstissä? Rakenteen ja merkityksen välisen suhteen ongelman olisi voinut esittää jo ensimmäisessä luvussa. Nyt se tulee kirjoitettunakin esiin lähes läpi kirjan. Vaikka kirjan alkuluvussa ansiokkaasti selvitetään elämäkertatutkimuksen teoreettisia ulottuvuuksia, ei silti ole aina selvää, millaisesta näkökulmasta luvut on kirjoitettu. Lukijan kannalta ehkä parempi vaihtoehto olisi ollut havaintojen rohkeampi tyypittely ja tekstin kirjoittaminen vahvemmin kertomuksen muotoon "aidossa" konstruktionistisessa hengessä.

Oppiminen ja elämänhistoria valottaa koulutuksen ja oppimisen merkityksiä runsaan puolen vuosisadan ajalta taaksepäin- jos nuoruuden kokemukset synnyttävät sukupolviaseman, yhteisten kokemusten merkitysvaraston, millaisia oppimiskokemuksia syntyy siinä tämän päivän sukupolvessa, jolla ei vielä ole muuta nimeä kuin $\mathrm{x}$ ? Kirja haastaa myös pohtimaan, millaista reaalihistoriaa tämä sukupolvi tekee? 